\title{
7 \\ Up the Coast of China and Arrival at Tianjin
}

On 13 July 1816, five British ships left Hong Kong Island and set a course for the Gulf of Bei Zhili in northern China. ${ }^{1}$ The initial British encounter with China after the embassy arrived in the north and before it was embroiled in the kowtow controversy was largely informal and cordial. Ensuing stressful confrontations with Chinese officialdom, however, simply reinforced British stereotypes of the Chinese. Perceptions of China soon came to duplicate Barrow's views portrayed in his book Travels in China (1804). This account functioned as a primer assisting British understanding of the novel environment in which they now found themselves, and was referred to constantly by members of the Amherst Embassy during their journey.

The intrusion of British ships into China's northern seas represented a physical demonstration of British technical and military superiority seen only once before at the time of Macartney in $1793 .{ }^{2}$ While the ships were following Macartney's route, there were still considerable dangers for such large vessels in little-charted waters. Captain Basil Hall complained that the best charts were 'nearly useless ... we frequently stumbled upon large groups of islands, headlands, and bays, of which no mention had ever

1 Bei Zhili literally means 'northern directly ruled' province. There was a Nan Zhili or 'southern directly ruled' province around Nanjing.

2 Earlier British naval expeditions to the north Asian region included Captain Cook who had sailed down the eastern coast of Japan on his way to Macao during his third voyage in 1776-1780, and Captain William Broughton who stopped at Macao in 1796-1797 during his exploration of the Japanese islands. 
been made' (1840/1865, p. 7). Assisting navigation was 'Massey's patent sounding machine', the latest British scientific tool used for measuring sea depths (Hall, 1840/1865, p. 7). Hiring Chinese pilots had been canvassed briefly in London, but was soon dismissed on grounds of the need for keeping the mission a secret from Chinese authorities, as well as doubts over their competency to navigate large ships in waters north of Guangdong province. ${ }^{3}$ Trust was placed instead in British seamanship and technology to steer the embassy safely to the Yellow Sea.

Fast progress was made through the Straits of Formosa, passing along the coasts of Guangdong and Fujian provinces until the ships entered the Donghai or Eastern Sea (M'Leod, 1818/1820, p. 21). Jeffrey wrote in his journal that the Alceste and General Hewitt often towed the Discovery and Investigator 'by which means we got on rather faster' (Jeffrey Amherst, n.d., n.p.). The British were in a buoyant mood due to fine weather and the prospect of encountering new and 'stirring scenes' of China (Davis, 1841, p. 10). Chinese fishing boats periodically approached the Alceste, but, according to Jeffrey, British attempts to bargain with them failed as 'they did not like to have any dealings with us' (Jeffrey Amherst, n.d., n.p.).

The ships cleared the Formosa Straits on 17 July and passed the Zhoushan Islands the following day. Swift progress continued. Several geographical landmarks named by Captain Erasmus Gower of the HMS Lion during the Macartney Embassy were noted. These included Staunton's Island, Cape Gower and Cape Macartney. Captain Maxwell followed Gower's example and named a cape situated at the point of the promontory of the Shandong peninsula 'Cape Amherst'. The naming of the China coast after British officials appears incongruous given the cultural antiquity of the sea route, but little shipping was seen apart from fishing boats, which gave an erroneous impression that the coast was deserted. A vigorous local coastal trade, pointed out by Samuel Ball in his secret report, ${ }^{4}$ was taking place much closer to shore out of sight of the British ships.

3 The Macartney Embassy sought to procure Chinese pilots at Zhoushan to conduct the mission to Tianjin. They had little nautical skill, however, and the British had to rely on their own resources (Cranmer-Byng, 1962, pp. 65-66).

4 This report, as noted above, is reproduced in Appendix D. 


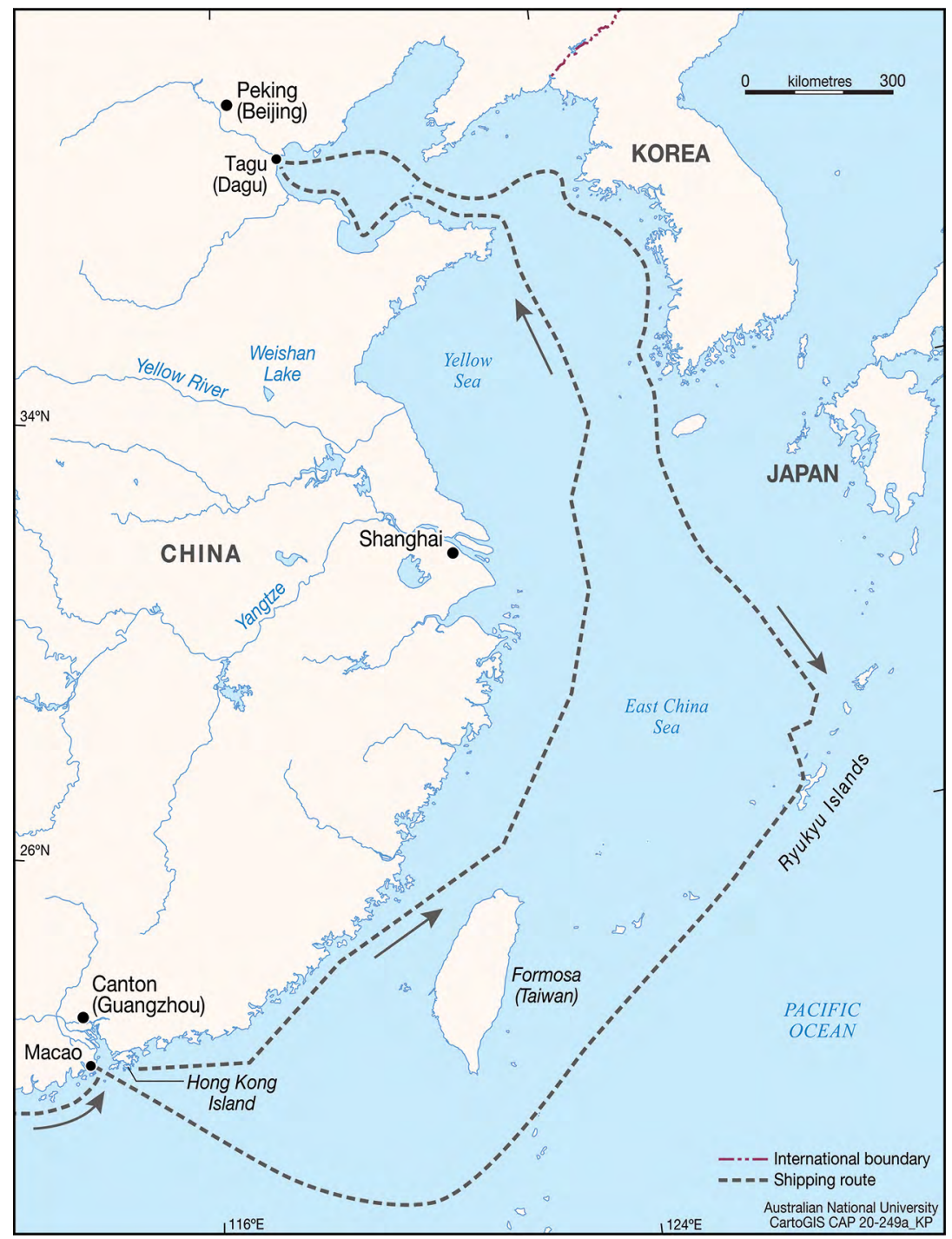

Figure 5: Route taken by the British ships to the Gulf of Bei Zhili in northern China.

Note: After depositing Amherst and his embassy at 'Tagu', the HMS Alceste and HMS Lyra proceeded to chart the coast of Korea and the Ryukyu Islands before travelling onto the Canton port of Whampoa to collect the embassy.

Source: CartoGIS, College of Asia and the Pacific, ANU. Based on map in M'Leod (1818/1820, p. 28). 


\section{The Yellow Sea}

The British reached the Yellow Sea in only 12 days. Little of China had been seen apart from a thin ribbon of land that came in and out of view as the ships passed. Davis wrote later on the occasion of sailing past the Fujian coast:

We cast a wistful eye from our ships at the China coast, a few miles off, and with the help of a glass could discover a few scattered villages, apparently fishermen's houses. The shore was generally low, with barren hills a little way inland. (1841, p. 12)

Of more immediate concern was the severe discomfort from extreme humidity endured by the English. Abel wrote:

I can ... give no better notion of the excessive moisture of the atmosphere in the China seas during the S.W. monsoon, than by stating the Leslie's hygrometer is not graduated to a sufficient extent to mark its degree, that our clothes were as wet as if they had been exposed to a smart shower of rain. (1818, p. 64)

The squadron finally came to a halt in the Gulf of Bei Zhili, called 'Pe-che-lee' by the British, on 26 July 1816 . Amherst took the opportunity of following Macartney's precedent and called on all the 'gentlemen, servants, musicians, and guard of the Embassy to be assembled on the quarter deck' where he addressed them on 'the importance, and indeed the absolute necessity of conducting themselves with sobriety and decorum during their residence in the Chinese dominions' (Ellis, 1817, p. 63). ${ }^{5}$ Further, trade with the Chinese was strictly prohibited as it was imperative to remove any suspicion that the prime aim of the embassy involved commercial interests.

5 Macartney ordered that a similar proclamation be communicated to the crew of the Lion and Hindostan on 16 July 1793 (Cranmer-Byng, 1962, p. 66). 


\section{First Contact with the Chinese: Fishermen and Mandarins}

The Lyra, meanwhile, had been sent on ahead to announce the approach of the embassy and anchored in three fathoms of water, six miles from shore. The rest of the fleet anchored in five fathoms of water, 15 miles from the mouth of the Baihe River (Ellis, 1817, p. 63). ${ }^{6}$

Captain Hall and Francis Toone, the interpreter on board the Lyra, were instructed to make contact with the local mandarins to inform them of the embassy's arrival by way of an official letter written by Amherst and placed in Toone's care. The letter, following Chinese protocol, contained the names of the embassy's officials and included a list of the presents. Amherst referred to the Macartney Embassy and requested that a similar number of boats be made available for the transport of his embassy to Peking (Ellis, 1817, p. 63). Toone, however, was instructed not to visit the shore to avoid the prospect of some questions of an insidious and embarrassing character' on the motives of the embassy (Ellis, 1817, p. 63). The pair set off in a rowboat from the Lyra for the distant mouth of the Baihe River, hoping to find some way of notifying the local authorities of the embassy's arrival.

\section{July 1816}

Hall and Toone decided to approach a Chinese fishing junk lying at anchor near the Lyra. Chinese reactions at noticing some Europeans rowing towards them can only be imagined. British sensibilities, on the other hand, were shocked at the discovery that the fishermen were as 'naked as savages' wearing only a jacket over their shoulders but 'no clothing for the lower part of the body' (Morrison, 1820, p. 16). The moral assessments are Morrison's as Hall neglected to mention this point in his account, perhaps out of sensitivity to the possible response of his readers. The fishermen received the Englishmen most cordially and invited them on board where they were offered a seat on a bench placed on the quarterdeck. Communication at first was difficult as Toone did not understand their dialect, but matters resolved themselves when he reverted

6 The Baihe or White River is now known as the Haihe or Ocean River. 
to the use of Chinese characters where 'every man in the boat understood him' (Hall, 1840/1865, p. 7). While Toone was busy communicating with the head fisherman, Hall described 'falling into the hands' of the crew whose curious attention focused on his dress. Particular interest was shown towards his shoes, which Hall removed for examination while his epaulettes were unbuttoned and drew the 'greatest wonder'. Hall's pocket compass was also discovered and its purpose comprehended immediately by the fishermen: 'three or four of them carried it off to compare with their own needle' (Hall, 1840/1865, p. 7, emphasis in original). The fishermen's delight on recognising the function of the compass was commented on by Hall who acknowledged the important role of common understanding and awareness serving to break down cultural barriers. The fishermen returned the compass to Hall 'with much complacency' (Hall, 1840/1865, p. 7).

A sudden downpour forced Hall and Toone to take shelter inside the junk's cabin, which represented one of the few occasions during the travels of the embassy in China where the English were privileged to see inside any local abode. The cabin was 'a neat little apartment, round which were spread a few fur skins, and very comfortable pillows in small pigeon-holes, or sleeping berths' (Hall, 1840/1865, p. 7). Threads of copper coins were noticed on a table and numerous Chinese books were scattered around the room. Hall was fascinated with the Chinese hairstyle described as the 'well-known long tuft or tail, reaching from the back of the head nearly to the ground; all the rest of the head being shaved' (Hall, 1840/1865, p. 8). Chinese reaction to the British, on the other hand, centred on the absence of 'tails'. Hall wrote perceptively:

Such is the effect of custom, that nothing in our dress or manners excited so much surprise in these people, or appeared more preposterous in their eyes, than our contriving to exist without long tails. $(1840 / 1865$, p. 8$)$

The cordial meeting came to an end when the fishermen refused to accept Amherst's letter or take it to the local authorities. Hall and Toone offered some silver dollars as thanks for their hospitality but the coins were not recognised and the fishermen tried to hand the money back. 'The fishermen', Hall wrote, 'finding us determined not to take back the money, very unceremoniously pitched it into the boat as we rowed away' (1840/1865, p. 8). M'Leod, the physician accompanying the Alceste, noted that the universal currency of Spanish silver dollars held no meaning for 
the Chinese; rather, these coins were 'melted down, the moment [they fell] into the hands of a Chinese at Canton' (M'Leod, 1818/1820, p. 34). The British, meanwhile, decided to send a boat to the river entrance on the following day in an attempt to make contact with local officials.

\section{July 1816: The Mandarins Come On Board}

Two large junks approached the Lyra the following morning and Hall described 'two Chinese officers, middle-aged, portly, comfortable-looking ... with very dark mahogany-coloured faces' who came on board. Their names were Chang-wei and Yin. Chang-wei was Chinese and a civil officer who wore a blue button, while Yin was a Manchu military officer who wore a red button. ${ }^{7}$ Their appearance, Hall related, caused a sensation among the British crew because this was the first time they had seen 'Chinese dress ... except on teacups and saucers' (1840/1865, p. 7). His perceptive comment reflects that British images of 'China' and its people for the majority of Englishmen were formed exclusively from their representations on the export wares from Canton that flooded the British market during the eighteenth century. ${ }^{8}$ British astonishment expressed on board the embassy ships can also be read as signifying the difference noted in Chinese identity between the mandarins or 'gentlemen' who came on board the British ships at this time, with those Chinese seamen seen previously at Batavia or on the local fishing boats.

The first social encounter between the British and the mandarins was an enjoyable occasion due largely to the personality of Chang-wei, the younger official, who 'made himself at home in a moment. He laughed,

7 Tuck (2000) noted that Staunton and Ellis grew to like both mandarins whose junior rank spared them any repercussions from the emperor at the time of the eventual dismissal of the embassy. Tuck further noted that Chang-wei was promoted to a judicial commissionership in Shantung soon after the embassy's departure and left the embassy on 12 September 1816. Yin left the embassy on 17 September 1816. 'Their task seemed to be to see to the daily wants of the Embassy ... and to keep the Embassy in touch with the two great officials conducting the mission to Peking' (p. xxvii).

8 William Alexander (1767-1816), the draughtsman with the Macartney Embassy, produced over 2,000 sketches of images and scenes depicting China and Chinese life that were first published in Sir G. L. Staunton's (1797a) Authentic Account and subsequently in 1805 and 1814 . Access to these was, of course, restricted to the most privileged classes of British society. Alexander's artwork can be found in Legouix (1980). 
joked, and skipped about, examining everything more like a child than a grave public functionary' (Hall, 1840/1865, p. 7). Chang-wei enjoyed himself especially in Hall's cabin. Here he:

placed himself unceremoniously, but not rudely, at the head of the table, and reaching his arm out, drew a book from the library, opened it, and, with great affected formality, turned the leaves backwards and forwards till he lighted upon the title page. He then held it up before him, examined it with his eyes nearly closed,- - turned it upside down, sideways and in every direction,- - twisting his face into all sorts of ridiculous forms, expressive of his amusement and surprise at the strangeness of what he saw; - then jumping on his feet, displayed the book to his wondering attendants, who had taken possession of the skylight, and were thrusting their heads down to see what was going on. (Hall, 1840/1865, p. 7)

Harmonious and jovial relations between the mandarins and the British were improved further with the arrival of a couple of bottles of cherry brandy. The mandarins, Hall related, 'no sooner drank, than they filled their glasses again, and were not contented till all their attendants had followed so good an example' (1840/1865, p. 7). Eventually, Hall added, it was high time to come to business. Predictably, after all the cherry brandy, the mandarins declared their willingness to take charge of Amherst's letter and return with it to Dagu to place it in the hands of the senior legate. Communication with the mandarins was difficult and Toone once more reverted to the use of Chinese characters to get messages understood, much to the mandarin's surprise and amusement (Jeffrey Amherst, n.d., n.p.). ${ }^{9}$ The practice was taken up by Chang-wei, who finding himself misunderstood and seeing no ink or paper, improvised by 'dip[ping] his finger, without apology, into his neighbour's glass [of cherry brandy] — for the contents of his own had long disappeared-and painted the symbols on the table' (Hall, $1840 / 1865$, p. 8).

The Chinese guests were not easy to get rid of. Hall wrote that while the mandarins were:

9 Jeffrey wrote that the mandarins were 'much surprised and amused at seeing Mr. Toone talk and write in the Chinese language'. 
pledging the emperor in cherry brandy, the boatmen were taken in charge by the sailors who, in like manner, were initiating them, with great success, into the mysteries of grog and salt-beef. $(1840 / 1865$, p. 8$)$

The mandarins, armed with Amherst's letter to the local governor, finally departed. The Lyra weighed anchor and set out to rejoin the rest of the squadron anchored 10 miles out at sea.

Captain Hall came on board the Alceste the following morning with news of the mandarins' visit to the Lyra. Amherst was informed that the governorgeneral of Bei Zhili had signified his readiness to receive the embassy at the mouth of the Baihe River. Bad weather, however, prohibited any further communication from shore and the British had a couple of anxious days waiting for news. Time was spent observing the great number of junks and boats that passed by them on their way to Tianjin. The Chinese were initially shy in approaching the British squadron, 'alarmed perhaps by the novel appearance of our ships', but gradually became bolder and approached near enough for close mutual inspection (Jeffrey Amherst, n.d., n.p.). Jeffrey, no doubt parroting the sentiments of his father, was pleased that the cooler weather allowed them to 'dress something like Englishmen-before we need[ed] to go without our coats and waistcoats' (Jeffrey Amherst, n.d., n.p.). He also joked about the happy disposition of Hall's mandarin visitors who were 'always laughing and cherry [sic]' (Jeffrey Amherst, n.d., n.p.).

\section{July 1816: The Embassy Conductors Come On Board}

On the morning of 31 July, a small junk with streamers and flags portraying 'a dark coloured dragon' approached the Alceste. On board were four mandarins, including Chang-wei and Yin (Ellis, 1817, p. 65). This visit represented Amherst's first direct contact with the Chinese authorities. The mandarins were kept waiting in Captain Maxwell's cabin where 'they were regaled with wines' and engaged in conversation with Morrison while Amherst prepared himself for their reception (Jeffrey Amherst, n.d., n.p.). Amherst wore his Parliamentary robes while the other civilian members of his suite wore their Windsor uniforms. The mandarins were subsequently conducted by Morrison, who acted as the interpreter at the meeting, 'through a passage formed by the other gentlemen of the 
Ambassador's suite' to Amherst's cabin where Amherst, Staunton and Ellis were waiting to receive them (Abel, 1818, p. 69). Amherst, according to Jeffrey, was seated on the sofa with Staunton on his left, the place of honour in China. Ellis sat on Amherst's right while Jeffrey 'stood behind the sofa ready to carry [his] father's train' (Jeffrey Amherst, n.d., n.p.). The mandarins made a very low bow on entering the cabin and seated themselves where they were served cherry brandy as the British had no means of serving tea in the Chinese fashion. The choice of beverage was 'by no means to the[ir] dissatisfaction' (Ellis, 1817, p. 67). Jeffrey, meanwhile, was a focus of attention. He wrote that Morrison had taught him 'the Chinese for 14 which was my age ... and ... it turned out, [that] one of the mandarins asked me my age as soon as I was presented to him and was not a little amused at my answering him in his own language' (Jeffrey Amherst, n.d., n.p.).

The British believed the purpose of the meeting was largely complimentary as its chief objective was to enquire about the number of people in the embassy and the nature of the presents (Ellis, 1817, p. 66). Such an enquiry in Chinese terms formed part of a body of fundamental protocols governing the reception of any prospective embassy at the Qing court. The British were informed that the superintendent of salt duties at Tianjin, a mandarin appointed by special commission to the embassy, was waiting to receive Amherst on shore. His name was Guanghui, referred to as 'Kuang' or the 'legate' by the British, who was destined to escort the embassy to Peking and back to Canton. ${ }^{10}$ Immediate arrangements were made for Morrison and Cooke to return to shore with the mandarins to meet with Guanghui to make arrangements for the disembarkation of the embassy. Two other pieces of information were relayed at the meeting. The first was the disturbing intelligence that the current governor-general of Bei Zhili had been removed and was due to be replaced by a man named Sulenge, called 'Soo' by the British, who had been the recent viceroy at Canton and whose disposition towards the British was particularly hostile. Ellis thought this change would be most unfortunate as the viceroy 'will probably be disposed to connect the present embassy with the late discussions at Canton in which he was so

10 Tuck (2000, p. xxviii) pointed out that Guanghui was referred to as 'Kwang' by Ellis, as 'Quang Ta-zin' by Staunton and as 'Quong' by Amherst. He was a Manchu and a bond servant of the imperial household. 
actively engaged' (Ellis, 1817, p. 66). ${ }^{11}$ The second piece of intelligence was that the Jiaqing emperor was due to depart for his summer retreat at Jehol on 9 September, leaving little time for embassy business at Peking.

Evidence that the Chinese had studied 'the minute circumstances relating to the former Embassy' was shown when one of the mandarins asked if there was a portrait of the emperor on board. A print of the Qianlong emperor from the time of the Macartney Embassy was produced at which time the mandarins became very anxious and 'displayed the greatest embarrassment' (Davis, 1841, p. 32). Davis recalled that they rose from their seats and begged that it be put away or otherwise it would be necessary for them to 'perform the prostration' before it (1841, p. 32). The mandarins also spent time looking around the cabin where their gaze fell on some fine pieces of English bone china. They were astonished to learn that these were made in England and not at Canton; even greater disbelief was expressed by the mandarins when being told that finer specimens of china were available in England.

Ellis was disappointed with his first encounter with Chinese officials:

Their dresses were common; and certainly, their general appearance was neither respectable nor elegant: comparing them with persons of correspondent rank in Persia, Arabia, or Turkey, I should say they were inferior in outward respectability. The most remarkable part of their dress is the straw conical bonnet, with hair dyed red, hanging over it. Their complexions were dark and their features coarse. $(1817$, p. 66)

The mandarins, according to Jeffrey, were 'pretty fresh' by the time they departed the Alceste but were still capable of 'measuring the length and breadth of the Alceste and in counting the number of guns she carried' (Jeffrey Amherst, n.d., n.p.).

11 The British later discovered that 'Soo', or Sulenge, had not been a governor at Canton but rather the Hoppo who had received Macartney at Canton at the completion of his embassy. He was currently a most senior mandarin holding the position of president of the Board of Public Works. 


\section{July 1816: Morrison and Cooke Visit the Mainland}

Morrison and Cooke travelled to Dagu in a boat from the Discovery manned by Lascars under the command of Captain Crawford. Arriving at the port, described by Morrison (1820, p. 16) 'as a poor village', the accompanying mandarin displayed 'the most civil behaviour' in attempting to shelter the Englishmen from the heavy rain. After an uncomfortable journey in Chinese carts along wet and muddy roads, Morrison and Cooke reached the temple where Guanghui and the other mandarins delegated to escort the embassy, including Chang-wei and Yin who had earlier visited the Lyra, were waiting.

Guanghui, or the legate, described by Morrison (1820, p. 18) as a Tartar and 'a little man, about 58 years of age; pleasant and conversable ... but artful and fraudulent' opened proceedings. ${ }^{12}$ Morrison was asked 'in a cheerful tone' a number of questions customarily addressed in Qing diplomacy: How far had the embassy come? Had the embassy stopped at Macao? Had the embassy met the ships that he had sent and how many British ships and how many people were in the embassy's entourage (Morrison, 1820 , p. 18)? ${ }^{13}$ On learning that the embassy had 75 members, Guanghui requested that the number be reduced to 50 by dispensing with the guard and the band, to which Morrison replied that an extra 25 people could be of little consequence to so great an empire, leaving the legate with little choice but to agree (Morrison, 1820, p. 18). The meeting closed with an announcement that Chang-wei and Yin would pay a call on Amherst the next day. Morrison thought the meeting was an 'intended haughty reception'. He and Cooke retired and had dinner in the 'Chinese manner' (Morrison, 1820, p. 18).

The Englishmen climbed the stairs to the upper storey of the temple after dinner to admire the view where Morrison met a minor Chinese mandarin who was an excellent source of unofficial intelligence. He learned on this occasion that the embassy would not be staying long at Peking and,

12 Platt (2018, p. 168) referred to Guanghui as 'Zhang' and the 'handler' of the embassy. 'Zhang' is the only mandarin referred to by Platt, apart from the high ranking Heshitai, known as 'the Duke' who encountered the British for the first time at Tongzhou on 20 August 1816.

13 Morrison noted that no Chinese ships had been sent. 
unlike the Macartney Embassy, would not be travelling to Jehol. Rather, it was the Qing court's intention to receive and dismiss the embassy as quickly as possible.

Following a very uncomfortable night spent at the temple with only a bench to sleep on and no blankets or pillows, Morrison and Cooke travelled back to the river in 'the wretched carts of the country' before enduring a very rough sea passage back to the British ships (Morrison, 1820 , p. 19). Morrison was so fatigued from his trip ashore that he had to rest for the next couple of days. He later received an apology from the Chinese for their impolite hospitality towards him and Cooke.

\section{August 1816: The Mandarins Visit Amherst}

Final arrangements for the embassy's disembarkation were delayed by the 'blowy weather' preventing the mandarins from travelling out to the Alceste (Jeffrey Amherst, n.d., n.p.). Calm weather returned on 4 August and several large junks, bearing red flags announcing the presence of Chang-wei and Yin, finally approached the Alceste. Yin had brought his 11-year-old son. ${ }^{14}$ British protocol was broken on this occasion with the seven-gun salute being fired as the mandarins approached the ship, rather than when they came on board, in order to not 'needlessly shaken [their] tender nerves' (Hall, 1840/1865, p. 9). The Alceste's quarter deck was lined with two columns of British marines. The band played while the mandarins scrambled up its sides with great difficulty 'owing to the load of state-robes with which they had encumbered themselves for the occasion' (Hall, 1840/1865, p. 9). Captain Maxwell, resplendent in his full uniform, greeted the mandarins who showed much 'involuntary surprise' when inspecting the marines and witnessing the presentation of arms. The full military reception impressed Abel who drew a comparison between British splendour and the mandarins' appearance:

They gave me no very exalted notions of Chinese magnificence ... plainly dressed, and attended by a train of very shabby looking fellows ... the appearance of the whole party was strikingly

14 Yin was later described by Abel (1818, p. 144) as 'an old soldier, with ruddy complexion and laughing eyes, [who] cared very little about the arts or sciences of his own or any other country. The only produce of Europe that seemed to interest his attention was port-wine or cherry-brandy'. 
contrasted with the very tasteful and imposing splendour which surrounded them on board the Alceste. Her clear and ample decks, her well arranged rigging, her formidable artillery, her men prompt and orderly, and her officers in full uniform, formed a picture of propriety and order, of magnificence and power. (1818, p. 70)

Staunton and Ellis conducted the mandarins to Amherst's cabin and Amherst greeted them wearing his ceremonial robes. Guanghui had sent his apologies, explaining that his exalted rank freed him from the obligation of travelling 'eight or ten miles on the open sea to pay a visit of ceremony' (Hall, 1840/1865, p. 9).

The mandarins were seated in the place of honour on Amherst's left following Chinese protocols, while Staunton and Ellis sat in a row of chairs situated on the right-hand side. Morrison overheard Chang-wei tell his servant that he would have far rather preferred to have been placed in line with the ambassador, indicating the problems implicit in protocols of seating arrangements that continued to be a major concern in future official meetings between the British and Chinese (Morrison, 1820 , p. 20). The diplomatic encounter soon turned into a farce due to interruptions by Chang-wei and Yin's numerous attendants, who, curious to catch a glimpse of the ambassador, kept trying to enter the cabin where they were resisted by the British. British sensibilities at this time were also offended by the 'disagreeable odours' emitted by the Chinese, both of 'garlic and asafoetida', as well as the 'repulsive atmosphere' that surrounded them resulting from 'a want of cleanliness' (Abel, 1818, p. 70).

Curiosity over dress was not confined to Chinese fishermen. The mandarins' appearance of long beards and 'two enormous claws on the left hand', described by Morrison as rendering 'the limb useless to them', was particularly disconcerting to the British (M'Leod, 1818/1820, p. 24). M'Leod (1818/1820) thought they 'resembled bulky old women with their clumsy boots' (p. 24). The mandarins, in Morrison's (1820) opinion, were embarrassed by the 'novelty of their situation' because they had never seen Englishmen before (p. 20). He picked up also on the nuances of meaning in the discussions held among the Chinese as they worked out their answers. He wrote that 'An old servant, in a loud tone, stood prompting and explaining for Yin'. Morrison checked him by saying 'he understood the master better than the servant' (p. 20). 
Chang-wei asserted that his government's lack of preparations was due to the premature arrival of the embassy in northern China. Nevertheless, Amherst was informed that a highly ranked minister of state was waiting at Tianjin to receive him, and confirmed Morrison's earlier intelligence that the embassy's imperial audience was scheduled for Peking rather than Jehol. After receiving a list of embassy personnel and presents, Changwei asked the British about the objective of the embassy. Its purpose, the British affirmed, was to confirm and strengthen the friendship and alliance of the two courts. A formal letter with a detailed explanation of British goals was being prepared and would be presented to the minister at Tianjin along with a translation of the Prince Regent's letter to the emperor. The next question concerned the proposed manner for the embassy's return. Amherst replied that it was intended to follow Macartney's precedent and travel overland to Canton. The mandarins, on learning this information, 'made no reply' (Amherst to Canning, 8 August 1816, in BL IOR G/12/196 (Reel 1) F 193).

Chang-wei and Yin next raised the unwelcome issue of the ceremony. Amherst wrote later in his official report:

Next came a question which altho' prepared for its early discussion I hardly expected would have been put to me so soon. I was asked as to my knowledge of the Ceremony to be performed at the time of my presentation to the Emperor, and was expected to be ready for its performance. I said that I should be prepared to approach the Emperor in the most respectful manner possible, and being anxious to avoid entering at that time into further particulars an endeavour was made to turn the conversation to other subjects. (Amherst to Canning, 8 August 1816, in BL IOR G/12/196 (Reel 1) F 193)

The mandarins were diplomatic. They told Amherst:

That England was an important Country, and that the attention which the emperor was about to shew us were not bestowed on embassadors from every nation. Lest however this compliment should be treated too high something was said as if the long and fatiguing voyage we had made was to be considered as our special title to His Imperial Majesty's favour and attention. (Amherst to Canning, 8 August 1816, in BL IOR G/12/196 (Reel 1) F 194) 
Staunton, ironically given his fame as the 12-year-old at the Qianlong court, failed to mention Yin's son in his account of the embassy. The boy knelt before Amherst on one knee 'with much grace and modesty' suggesting that he had been instructed in the British custom of respect and had been told by his father to honour it (Ellis, 1817, p. 74). Jeffrey, in return, was presented to the two mandarins who 'seemed highly pleased with him' (Davis, 1841, p. 37). The two boys 'made acquaintance with each other' and Hall commented on the effect of children breaking down the 'ice of ceremony' among cautious and distrustful people (1840/1865, p. 9). Jeffrey's presence served to delay the mandarins' departure while they engaged in cheerful conversation with the British relieving them of 'much needless formality' (Hall, 1840/1865, p. 9). The mandarins promised a delivery of provisions and left the Alceste. Ellis complained once more of the oppressive stench emitting from the departing Chinese that reminded him of 'the repose of petrifying garlic on a much used blanket'. He agreed with Barrow's assessment that the Chinese were 'a frowzy people' (Ellis, 1817, p. 74).

Hall, who had the 'leisure to watch what was going on', observed the return of the mandarins to their boats (1840/1865, p. 9). Yin, Hall wrote, had no sooner returned to his junk than he:

flung off his robes, his crape petticoat, his great unwieldy velvet boots with soles an inch thick, and his fantastical cap, and issuing forth with his pipe hanging out of one side of his mouth, and a pair of slippers on his feet, appeared on the deck of his vessel without one trace of grandee left. So anxious indeed was he to remove from our minds the idea of his being naturally the grave and austere personage we had seen before, that he immediately set about monkey tricks, as they are called at sea, and diverted himself with throwing peaches to the young midshipmen, who, in a correspondent taste, had climbed into the rigging, and were not slow to better this instruction. (p. 9)

A procession of eight large junks with red swallow-tailed flags and one bearing the ensign of the imperial dragon approached the British ships soon afterwards bearing a present from the emperor that included 10 bullocks, 20 sheep, 20 hogs, 100 ducks and fowls, a great store of vegetables and many boxes of tea (p. 9). The Chinese carriers who came on board with the produce were warmly received by the British sailors who: 
paid them the most obsequious attention, escorting them around the decks like ladies, smoothing down their long tails, joking and talking with them ... not caring whether John Chinaman ... understood them or not. (p. 9)

The Chinese visitors were invited to sit down in the midshipmen quarters but when they attempted to rise from their seats they 'found themselves like Gulliver, for their wicked entertainers had tied each by his long tail to the back of his chair' (p. 9). Initially angry at such abuse, the Chinese soon saw the humour of the occasion and all parties 'joined in the laugh' (p. 9). The British trick, according to Hall, hereafter became well known among the Chinese who, on subsequent visits to British ships, took the precaution of 'coiling their tufts around their heads, out of the reach of practical jokes' (p. 10).

Some of the bullocks sent by the emperor had drowned on the outward passage. The British waited until the Chinese had departed before throwing the carcasses overboard and were astonished when people on passing junks scooped them up and proceeded to prepare them for cooking. M'Leod thought the practice disgusting and although he had yet to set foot in China had already judged that the Chinese 'eat in a putrid state, dogs, cats, rats, and in fact, all manner of carrion and vermin' (1818/1820, p. 27). He added that the British much preferred to live 'on our own salt beef' (p. 27).

The junks that brought the mandarins, as well as those that had brought the supplies, remained moored beside the British ships. The larger junks, the British learned, were scheduled to offload their luggage and the emperor's presents the following day. The Chinese carriers were astonished at the amount of luggage and furniture required by the British on their mission, leading Davis (1841) to comment on their 'self-denying and frugal habits' compared with their British counterparts:

A mat to spread out as a bed, and a hard, hollow pillow of woven rattans, together with the smallest possible box for garments, is all that they generally want for themselves. (p. 39)

Amherst invited the mandarins to dine on board the Alceste but this was declined due to Chang-wei's dread of 'passing from one vessel to another' in the choppy seas (Morrison, 1820, p. 21). Chang-wei's language, 
according to Morrison, was more civil than Yin's coarse and boisterous military manner (Ellis, 1817, p. 75). The mandarins sailed for shore that evening.

Hall was invited to breakfast on board a junk anchored close to the Lyra the following morning. Initially deterred by stories of Chinese eating 'bow-wow pies' and 'ragouts of cats', he bravely 'put on a good face' and accepted the invitation. He was very pleasantly surprised to find the deck spread with a grass mat on which was placed five or six bowls of finely boiled rice 'as white as snow' accompanied by a 'variety of savoury hashes and stews' (Hall, 1840/1865, p. 10). In the middle of the dishes was a large smoking platter containing 'what looked very like an omelette'. Shamsu wine was served in diminutive teacups and Hall thoroughly enjoyed himself, recording,

I had intended merely to go through the ceremony of tasting a morsel of rice to please these kind people, but ended by making a hearty meal, to the unspeakable delight of the Chinese boatmen. (1840/1865, p. 10)

Davis and Lieutenant Cooke went ashore a couple of days later to supervise the boats transporting the embassy and the presents to Tianjin. They were met by a civil mandarin wearing a light blue button and greeted with a three-gun salute fired by a company of Chinese soldiers. Vast crowds hoping to catch a glimpse of the English had gathered on the riverbank. Refreshments of tea and sweetmeats were served. Twentytwo boats were ready for the transportation of the embassy to Peking, including the baggage and presents for the emperor. A 'dinner-boat', suitable for the embassy suite to dine together, was promised at Tianjin (Davis, 1841, pp. 41-42).

Davis was not surprised to notice that the flags on the boats bore the Chinese characters for 'Koong-she' (gong shi) or 'Tribute Emissaries' but, being unauthorised to speak on the subject, made no comment (Ellis, 1817, p. 75). The emperor, he was informed, wished to meet Amherst without delay and Minister Sulenge was waiting at Tianjin to receive the embassy (Ellis, 1817, p. 75). Davis and Cooke were presented with gifts of apples, pears and peaches and returned to their ships in a journey that took five hours (Davis, 1841, p. 43). 
The unloading of the presents and the embassy's baggage onto the junks took a couple of days. The cheerful attitude of the Chinese workers and the orderly manner in which they carried out their task impressed the British and Ellis wrote that 'the lower orders, though curious, are by no means intrusive or impertinent' (1817, p. 77). Chinese insolence shown towards Europeans was obviously confined to the Cantonese: 'here, the men in the boats, and others of the same class, appear aware of the conduct required to persons of superior station' (Ellis, 1817, p. 77). Pressure was placed on the embassy to speed up its arrangements for leaving the ships due to the emperor's wish to meet them as soon as possible before leaving for Jehol. Amherst was informed that the emperor was especially looking forward to meeting Jeffrey and was planning a play and other amusements for him at Peking. He also enquired if Jeffrey 'had read any Chinese books', indicating that Staunton's impact at the Qianlong court had not been forgotten (Amherst to the Chairman and Deputy Chairman, sent from the 'Gulf of Pe-Che-le', 8 August 1816, in BL IOR G/12/196 (Reel 1) F 196).

\title{
Discussion on the 'Kowtow Question'
}

Their imminent departure from the British ships provided the last opportunity for Amherst and his commissioners to discuss strategies in a free and unrestrained environment. Hints dropped by Chang-wei and Yin convinced Staunton that the Chinese expectation of the English performing the kowtow had changed from a probability into a certainty:

\begin{abstract}
A great deal of anxious conversation [took] place between Lord Amherst, Mr. Ellis, and myself on the subject to the mission ... in all its bearings, and to contemplate all the possible contingencies by which its success may be either retarded or promoted ... so as to provide against being taken by surprise or off our guard; at least with respect to all the probable points of discussion-Among these, from the first, there was none which appeared more important, or more likely to be brought into early and serious discussion, than the question of compliance with the Chinese ceremony of prostration. (Staunton, 1824, p. 29)
\end{abstract}

Amherst's ambiguous instructions regarding the kowtow were noted where Barrow and Castlereagh instructed him to follow Macartney's precedent of bowing on one knee as ordered by the Prince Regent, while Buckinghamshire said he was free to perform the kowtow if expedient 
to do so for the attainment of his mission's objectives (Staunton, 1824, p. 30). As acknowledged earlier, Castlereagh's orders muddied the waters even further by stating that Amherst conform to the ceremonies of the Qing court 'which may not commit the honour of your Sovereign or lessen your own dignity' (Castlereagh to Amherst including two enclosures: Instructions, No. 1, 1 January 1816, in BL IOR MSS EUR F 140/43 (a)).

Staunton's presence in the embassy brought a new perspective to the issue as his local experience and deep reflection on the subject claimed authority over the views of the other embassy members. Following Amherst's request for his opinion, Staunton delivered a letter on 8 August with his view on complying with the Chinese ceremony of prostration. His prime concern was:

The effect it may have on the British character and interests at Canton, I beg to state that I feel strongly impressed with the idea that a compliance ... will be unadvisable, even though the refusal should be attended with the hazard of the total rejection of the embassy. I am fully sensible of the importance of the objects of the present mission; but I cannot bring myself to believe that their attainment would in the smallest degree be promoted by the compliance in question: and the mere reception (it could hardly be termed honourable reception) of the Embassy, would I think be too dearly purchased by such a sacrifice.

Staunton (1824) added:

There are some expedients by which the chief objections against the ceremony would be removed, but I am persuaded that the Chinese government is more likely to waive the ceremony, than to accede to any arrangement of that nature, that could be accepted as satisfactory. (p. 24)

Staunton's continuing belief that British exceptionalism would result in a possible dispensation from the strict protocols of Qing tributary ceremonial is evident in his statement. He argued strongly, however, that:

To recede at present from the precedent of Lord Macartney's Embassy, by a compliance unaccompanied by any condition similar to that for which Lord Macartney had stipulated, would be a sacrifice of national credit and character; and as such would operate injuriously to the trade and interests of the East-India Company at Canton; that such compliance (judging from my general knowledge and experience of the Chinese character, and 
more especially from the result of the Dutch Embassy in 1795) would not be likely to promote the attainment of any one of the objects we have in view, or in any way to benefit our national and commercial interests. (1824, p. 32)

Ellis, who thought it expedient for Amherst to perform the kowtow if this gained access to the emperor, followed up with his views on the issue in a letter dated 11 August. He thought the performance of the ceremony rested on 'matters of expediency' and that it was important to arrive at a consensus in order 'to clear the question of all personal feelings, which might lead us into a course of proceeding not quite in unison with the sentiments of the authorities at home' (1817, pp. 84-85). He concluded:

I have, however, such perfect reliance on Sir George Staunton's judgment and local experience, that I shall not hesitate in giving way on every point connected with Chinese usages and feelings, where my individual opinion might lead to a different conclusion. (pp. 84-85)

Staunton's and the Company's view, on the other hand, recognised that notions of British sovereignty were at stake. Metcalfe, the acting president of the Select Committee at Canton in Staunton's absence, succinctly summed up the Company's position: kowtowing before the Chinese emperor functioned as an acknowledgement of his rank as the 'Sovereign of the Universe', implicitly degrading the British sovereign and British envoys to the rank of tributary vassals (Metcalfe as quoted in Morse, 1926/1966, vol. 3, p. 263). Performing the kowtow would result in demoting British status, thereby allowing the Hong merchants at Canton the upper hand in acting roughshod over Company merchants. Discussion on the kowtow continued with Amherst deciding eventually:

That we should take the subject of compliance with ceremony into our consideration, unshackled by any reference to the instructions in question; and view it as a mere question of expediency, with regard to its influence more especially on the commercial interests of the East-India Company at Canton. (Staunton, 1824, p. 31)

The kowtow question remained open. Amherst, it was agreed, was free to perform the kowtow if the success of the mission was thought to depend on it (Staunton, 1824, p. 30). Relationships among Amherst and the commissioners were exceedingly close. Staunton wrote to his mother from the Alceste on 7 August 1816 that all the 'preliminary arrangements' 
of the embassy had been settled in 'a manner quite agreeable to my wishes'. Showing no signs of jealousy or resentment that Amherst had been appointed ambassador over him, Staunton continued:

I have found Lord Amherst everything I could possibly wishHe has not only been exceedingly kind and attentive to me personally, but appears disposed to pay every consideration to the suggestions and representations that I have occasion to make him. His Lordship's conduct and manner throughout is extremely conciliating ... yet without any sacrifice of dignity — and I therefore really think that our Government has been very fortunate in its selection. (Staunton Letters, HMS Alceste, on anchor in the Gulf of Pechelee, 7 August 1816)

Staunton also praised Ellis:

Mr Ellis is also [a] very pleasant, and intelligent young man, and I have little doubt of our continuing to act together with the greatest cordiality. The rest of the Gentlemen are likewise pleasant and respectable men, and form, with those who have accompanied me from Canton, a society of 20 persons - the whole partyServants, Soldiers and Musicians being 75. (Staunton Letters, HMS Alceste, on anchor in the Gulf of Pechelee, 7 August 1816)

Amherst, meanwhile, was uneasy about his forthcoming reception at Tianjin. Sulenge's exceptionally high rank raised concerns about the future of the embassy. Amherst wrote:

I am a little apprehensive that [Sulenge's appointment] ... is not to be considered altogether as a compliment, but rather as a design to introduce matters of ceremony or others such as was done in the case of the Russian Embassy in 1805 before our arrival at the Capital and possible to prevent our ever reaching the Capital at all. (Amherst: First Dispatch, to the Chairman and Deputy Chairman, sent from the 'Gulf of Pe-Che-le', 8 August 1816, in BL IOR G/12/196 (Reel 1) F 197)

Ellis also sensed that the presence of a high-ranking minister at Tianjin suggested 'that some propositions of importance, more especially touching the ceremony, were to be made there'. Fearful that the agenda at Tianjin left little time for negotiations, he predicted, 'The tempest is gathering, and it is difficult to say whether we should carry through it, or strike our masts and make everything snug' (1817, p. 73). 
Regardless of the diplomatic outcome of the embassy, the British were determined to travel back to Canton on the overland route followed by Macartney. Accordingly, plans had been made at the Admiralty in London to circumvent any Chinese attempt to force the embassy to return by sea by arranging for the early departure of the British ships. The Alceste and Discovery were to head north to explore the Manchurian and Korean coasts, while the Lyra and Investigator were to head south towards the Yellow Sea. It was then proposed that the ships would rendezvous at a point along the coastline of Shandong Province where they would separate. The ships of the Royal Navy, namely, the Alceste and Lyra, would head east towards the Ryukyu Islands, while the Indiamen sailed south to Macao, in the wake of the General Hewitt, which was tasked with sailing directly to Whampoa to collect tea (Tuck, 2000, p. xli, fn. 70). ${ }^{15}$

The members of the embassy enjoyed a fine dinner on board the Alceste and disembarked onto the boats carrying them to the port of Dagu on the morning of 9 August 1816 where they were 'to commit themselves, for a period of about six months, to Chinese hospitality' (Davis, 1841, p. 43). Amherst had made it his duty to 'make the situation of everybody in the Embassy as comfortable as possible' and reminded all who were travelling with him that the good conduct of the last embassy had 'excited the admiration' of the Chinese (Journal of Sir William Fanshawe Martin, 1817 , p. 23, in BL ADD MSS 41346-41475).

The embassy ships had been fully stocked with supplies arranged between the quartermaster of the Alceste, Mr Hickman, and the Chinese authorities. Maxwell told Amherst that Hickman had negotiated with a 'very civil mandarin'. He added:

How they came to understand what they said, I do not exactly know, but Hickman seems positive beef, mutton, greens and fruit were amongst the ... good things intended to be sent us by His Imperial Majesty. (Maxwell to Amherst, the Yellow Sea, Saturday, noon, 10 August 1816, in BL MSS EUR F 140/38 (a))

Maxwell requested, with a wink and a nudge, that Morrison give a mandarin 'a hint' that the sooner 'the supplies came the better':

15 Captain Murray Maxwell's obituary in 1831 noted the contribution made to British hydrography by these voyages. For example, the 'mainland of Corea was found more than a hundred miles to the eastward of the spot on [former] charts' (Gentleman's Magazine, September 1831, vol. 101, pt. 2, p. 273). 
As we are very anxious to move away from this very dangerous anchorage, (where betwixt your Lordship and myself, I would venture to ride, at any time a whole summer without the smallest apprehension) all the ships are getting very short of water. We shall therefore be on our way out of the Yellow Sea endeavouring to procure some ... The Pekin government may despair of catching us at Chusan [Zhoushan] above a very few days, but should your Lordship have any commands for me, a letter directed there might reach me. (Maxwell to Amherst, the Yellow Sea, Saturday, noon, 10 August 1816, in BL MSS EUR F 140/38 (a))

The embassy ships, soon after disembarking Amherst and his suite, 'slipped anchor, evaded the maritime authorities and made for the open sea' (Tuck, 2000, p. xxviii). ${ }^{16}$

\section{August 1816: The Embassy Lands in China and Early Negotiations on the Kowtow}

Seventy-five Englishmen left the British ships on the morning of 9 August 1816, bound for Dagu. ${ }^{17}$ Twenty gentlemen made up the ambassadorial suite while the remainder of the party comprised 17 servants, 12 musicians, 23 marines and three mechanics (Staunton, 1824, pp. 36-37). The group was joined on its first night ashore in China by some men from the ships, including captains Maxwell, Hall and Campbell, who accompanied it to Dagu before returning to their ships the next day to prepare for weighing anchor and setting off on their respective missions on 11 August 1816.

Amherst's departure for the Chinese mainland was marked with an elaborate display of British pomp and ceremony. The British ships fired a 19-gun salute while cheering crews lined the decks. Amherst and the two commissioners were seated in the Alceste's barge bearing the English standard at the fore and the Company's ensign at the mizzen. They led a procession of two lines of boats carrying the rest of the embassy personnel, the marine guard and the band playing martial songs. Davis noted later, 'The Embassy never again made so respectable an appearance until the

16 The ships left on 11 August 1816 and rendezvoused on 29 August 1816 in the waters off the southern coast of Shandong Province.

17 This number was 20 less than Macartney's entourage which included five German musicians and 53 military personnel. 
same boats met it on its return, in the river near Canton, and conducted it to the British Factory' (1841, p. 44). Nearing Dagu, the embassy suite transferred to Chinese junks for the final stage of their journey to the Chinese mainland.

Four to five hundred Chinese troops with their colours flying and music playing were lined up at the entrance of the river to Dagu where a threegun salute from a Chinese shore battery greeted the arrival of the British (Staunton, 1824, p. 33). The Chinese soldiers, in Ellis's view, appeared 'respectable' from a distance but Jeffrey noticed they were armed only with bows and arrows. Closer inspection, he reported, revealed they were not of:

A warlike appearance; first of all from their dress, and secondly from the slovenly way in which they stand; some with their toes turned in, others from their hands in their pockets and so on. (Jeffrey Amherst, n.d., n.p.)

Abel was dismissive also of their 'gaudy appearance' and observed that the troops were constantly moved up to the next point of the river once the embassy had passed (1818, p. 74).

Amherst was met at Dagu by a great number of mandarins who directed the British onto the Chinese barges carrying them to Tianjin. Flags bearing characters denoting 'Tribute Bearers' flew from the mastheads but the British decided not to comment (Abel, 1818, p. 73). Guanghui, the legate in charge of the embassy, visited Amherst and announced his regret that 'an ignorance of each other's language, prevented a more intimate and familiar conversation' and was disappointed on discovering that Jeffrey could not speak Chinese (Staunton, 1824, p. 34). 'The emperor', Jeffrey wrote, 'fully expected I could, because Sir George Staunton when he accompanied the last Embassy was about my age and could speak the language' (Jeffrey Amherst, n.d., n.p.). Guanghui was affable and wellmannered and stressed that his early visit was purely complimentary, but hinted that an imperial banquet was scheduled at Tianjin.

Amherst repaid the visit that evening where he met the high-ranking mandarin, Sulenge, for the first time. No formal discussion took place and Sulenge departed for Tianjin soon after. Jeffrey wrote:

Su entered his palanquin carried by four bearers and accompanied by an escort of horse archers, and set off on the eighty mile journey to Tien sing in order to receive the Embassy there. (Jeffrey Amherst, n.d., n.p.) 
The boats assigned for the embassy were a mixture of large, roomy vessels for Amherst and the commissioners, while the others were small and indifferent (Staunton, 1824, p. 35). Morrison (1820) described them:

They were divided into rooms: first was a kind of anti-chamber for servants; next a room in which to receive visitors; and farther back a bed-room. Some had four apartments, beside a place at the stern occupied by the boatmen, and used as a cooking-room. The Embassador's and Commissioner's boats were large and handsome, with streamers in the Chinese manner. Most of the others were too small for two persons, which was the general arrangement. (p. 25)

The first evening in China presented an immediate challenge to British culinary sensibilities on the presentation of a gift of cooked dishes for the evening meal chosen by Guanghui. Notable for the absence of cats and dogs, these nevertheless included trays of stewed shark fins, stag sinews, bird's nests and sea slugs (Abel, 1818, p. 74). Abel (1818) wrote, 'as it was the first time of partaking of Chinese fare, curiosity induced us to taste the made dishes, but their flavour did not tempt us to do more' (p. 74). Other unappetising offerings consisted of 'varnished' sheep, pigs and fowls (p. 74).

Regardless of the novelty of the food, the dining experience was unsatisfactory and chaotic for other reasons. The crates with Amherst's cutlery, crockery and table linen had been sent on to Tianjin. Jeffrey wrote, 'Many of our party were obliged to eat with the Chinese chopsticks [and] made pretty work of it' (Jeffrey Amherst, n.d., n.p.). There were no chairs or dining tables and Chinese tables had to be pushed together and stools were used as chairs. Beds and bedding had also been sent to Tianjin along with many boxes holding personal belongings. Servants rummaged through boxes and bags searching for their master's possessions, which left things in a considerable mess. The British spent their first night in China sleeping on bare boards in cold conditions with no blankets or pillows and plagued by hordes of mosquitoes. An added blow to British comfort was being prohibited by Chinese soldiers from taking a walk after dinner. Abel commented, 'We had little cause to look forward with much pleasurable anticipation to the liberty which we were likely to enjoy during our passage through China' (1818, p. 75).

First impressions of the Chinese countryside were disappointing, especially when compared with the picturesque scenery of Rio de Janeiro. Abel thought Dagu was 'destitute of interest' with flat, barren shores and 
mud houses. Crowds of silent people lined the riverbank and thousands of junks covered the waterway, impeding the progress of the embassy (Hall, $1840 / 1865$, p. 10). Ellis, on the other hand, noted improvements as the embassy barges approached Tianjin. Not only did the countryside appear well cultivated, but also some 'small inclosures in places remind[ed] us of England' (1817, p. 82). Ellis's tone even implied some warmth towards Chinese children noted in his observation that 'Chinese children must have a peculiar satisfaction in being dirty, as we observe them every where either sliding down the bank, or rolling themselves in mud' (p. 83). On the whole, Ellis's assessment of the Chinese at this early stage was positive and he wrote that 'My good opinion of the ordinary habits of the Chinese increases: they are orderly and good humoured to each other, and to strangers; not a single dispute has yet occurred' (p. 83). His perceptions had been softened by an earlier acquaintance with India and he was not as shocked as his compatriots with the appearance of the boat trackers described by Abel (1818) as 'miserable objects of wretched and naked men, tracking our boats and toiling often through a deep mire under a burning sun' (p. 76). Morrison (1820) painted an even bleaker picture of the boats propelled by human effort where groups of 20 or 30 'poor miserable-looking men' passed cords across their shoulders and walking forward in a leaning posture pulled the cords tied to the masthead of the vessel (p. 25). Jeffrey referred to seeing a body floating in the river that drew no reaction from the Chinese and thought it was the custom for poor Chinese to dispose of their dead in this fashion, accounting for 'the many dead bodies which we passed in our progress through China' (Jeffrey Amherst, n.d., n.p.).

\section{August 1816: Arrival at Tianjin}

The barges came to a halt at Tianjin at half past four in the afternoon of 12 August 1816, three days after leaving Dagu. Midshipman Martin wrote of British annoyance at the 'number of pleasure boats which flocked round our junks with parties in them who amused themselves by passing their remarks on us and criticizing our dress' (as quoted in Morrison, 1820, p. 29). A party of mandarins dressed in their ceremonial robes was waiting to greet the embassy, catching Amherst unprepared and in his dressing gown. Embarrassed, Amherst hastily retired to dress, leaving Morrison to explain British etiquette where the reception of visitors occurred sometime after a first arrival at a destination. Toone, Davis and Morrison were sent 
to meet Guanghui and Sulenge. Sulenge was described as a stooped old man of 70 who wore a red button. His complexion was marked with 'the small pox' and he was in the habit of deferring to Guanghui (Morrison, 1820, p. 27).

The British were received with a pleasing formality and were honoured with chairs situated to the left of Sulenge. The emperor, Guanghui informed them, regarded the British highly and favoured those who had travelled from such a great distance to pay their respects to him but, he supposed, they must be in a great hurry to return to England (Morrison, 1820 , p. 27). Morrison replied that an extra month or so was of no matter considering the distance the embassy had come and that Amherst would be insulted if he was forced to leave Peking before the customary 40 days allotted traditionally to foreign embassies. Guanghui next raised the subject of the king's letter to the emperor and pointed out that Macartney had already delivered his letter by this time during his embassy. Morrison corrected him. Macartney's journal stated clearly that the king's letter was delivered into the hands of the ministers at Jehol some weeks after the embassy had first arrived in northern China. Declining to comment, Guanghui's final questions concerned the rank of Jeffrey Amherst, as well as that of other members of the ambassadorial suite. These questions were later interpreted by the British as an attempt to confirm Staunton's presence and status within the embassy.

Morrison, Toone and Davis returned to the boats to inform Amherst that Sulenge and Guanghui were about to make a call. The legates were received by the British with 'great ceremony'. Amherst was informed of the emperor's intention to receive him and his embassy with even greater honours than those offered to Macartney at the Qianlong court. Focus at the meeting fell again on the presentation of the Prince Regent's letter to the emperor. The legates, Amherst was informed, were authorised to receive the letter at Tianjin rather than waiting to hand it to the ministers, as Macartney had done, at Jehol. Amherst, who had always planned to use the occasion of handing the letter personally to the first minister at Peking as the opportunity to raise the subject of the embassy's objectives, specifically those concerning trade, said he intended to wait until he met the minister. This, Sulenge informed him, was impossible. All business was to be conducted through him and Guanghui and there would be no dealings between the embassy and government ministers (Morrison, 1820 , p. 27). Amherst, on being informed of this, agreed to deliver a copy of the Prince Regent's letter to them on the following day. Sulenge then 
enquired after the identity of a young boy called Thomas Staunton that he remembered at the time of the Macartney mission and enquired if Staunton was he. Morrison, who was interpreting, hesitated to answer at which point Staunton came forward 'to introduce himself' (Staunton, 1824, p. 43). Staunton explained that he had been reluctant to speak until this time as his facility in the Chinese language had suffered due to long stays in England. Guanghui proceeded to compliment Staunton and told him that he had heard a great deal about him from his good friend, Sungyun, the late viceroy of Canton (Staunton, 1824, p. 43). Sulenge, Davis (1841) wrote, 'feigned surprise' at discovering Staunton's identity 'though there was every reason to suppose that the accounts from Canton must have long since put him in possession of this piece of information' (p. 64). Revealing his identity, however, was a great relief for Staunton, as every interview with the Chinese had been 'awkward and equivocal' (Staunton, 1824, p. 44). 'Whether or not', Staunton wrote, this was a preconceived plan of the legates to 'ascertain whether I meant to avow or conceal my identity with the youth in question, it is difficult to say' (1824, p. 44).

Staunton, meanwhile, had picked up some of the nuances in the legates' conversation regarding their invitation to the whole embassy to attend a banquet feast arranged for the next morning. He informed Amherst that the words 'tse-yen' (ciyan) or a 'repast conferred' meant that the banquet was more than an ordinary event. Indeed, Staunton added ominously, it forced British attention on 'the description of the imperial breakfast' that had proved so fatal to the Russian embassy in early 1806, after which Golovkin and his embassy were expelled immediately from China for refusing to kowtow (Staunton, 1824, p. 44). On the legates' departure, Amherst and the commissioners once more discussed the strategy to be pursued at the imperial banquet the next day. While the kowtow before the emperor remained an open question, unanimous agreement was reached that performing the ceremony before an imaginary presence of the emperor represented by a yellow curtain was totally inadmissible (Staunton, 1824, p. 44). 
This text is taken from Britain's Second Embassy to China: Lord Amherst's 'Special Mission' to the Jiaqing Emperor in 1816, by Caroline Stevenson, published 2021 by ANU Press, The Australian National University,

Canberra, Australia.

doi.org/10.22459/BSEC.2020.07 